\title{
Banal Catholicism, Morality Policies and the Politics of Belonging in Spain
}

\author{
Mar Griera ${ }^{1, *}$, Julia Martínez-Ariño ${ }^{2}(1)$ and Anna Clot-Garrell ${ }^{3}$ \\ 1 Department of Sociology, Universitat Autònoma de Barcelona, Bellaterra, 08193 Barcelona, Spain \\ 2 Department for the Comparative Study of Religion, University of Groningen, \\ 9712 GK Groningen, The Netherlands; j.martinez.arino@rug.nl \\ 3 Department of Sociology, University of Barcelona, 08034 Barcelona, Spain; annaclotgarrell@ub.edu \\ * Correspondence: mariadelmar.griera@uab.cat
}

check for updates

Citation: Griera, Mar, Julia

Martínez-Ariño, and Anna

Clot-Garrell. 2021. Banal Catholicism Morality Policies and the Politics of Belonging in Spain. Religions 12: 293. https://doi.org/10.3390/rel12050293

Academic Editors: Benoit Challand and Camil Ungureanu

Received: 9 March 2021

Accepted: 5 April 2021

Published: 22 April 2021

Publisher's Note: MDPI stays neutral with regard to jurisdictional claims in published maps and institutional affiliations.

Copyright: (c) 2021 by the authors. Licensee MDPI, Basel, Switzerland. This article is an open access article distributed under the terms and conditions of the Creative Commons Attribution (CC BY) license (https:// creativecommons.org/licenses/by/ $4.0 /)$

\begin{abstract}
The articulation between religion, politics and the law in contemporary European societies is a complex matter. In this article, we argue that classical secularization approaches fail to capture the ambivalent form of Catholicism in Europe, and we advance an alternative approach that reconsiders two elements: temporality and social space. Firstly, we propose to adopt an "eventful temporality", which enables the consideration of the impact of unexpected social and political events in altering the direction as well as shaping the public presence and form of religion. Secondly, we stress the need to focus on understanding the specificity of the different fields in which religion is mobilized, and the configuration and dynamics of each of these fields to explain the current weight of Christian majority churches in European societies. Drawing on empirical data from Spain, we examined the role and influence of Catholicism in three fields of public life: that of public services, that of morality politics and finally, that of the politics of belonging. In doing so, we identified their different temporalities (a long-term inertia in the first case, more abrupt changes in relation to the other two) as well as their specific dynamics in terms of actor constellations, issues at stake and symbolic repertoires.
\end{abstract}

Keywords: eventful temporality; banal religion; public services; morality policies; Catholicism; Spain

\section{Introduction}

The idea that the role and evolution of religion in society can be measured by means of the so-called "three Bs" (believing, belonging and behaving) (Lewis 2021) has deeply influenced sociological accounts and shaped statistical indicators of religiosity. From the mid-1960s, several scholars and research institutes have translated the "three Bs" into a set of measurable indicators of religiosity for the purpose of assessing and comparing different societies' degree of secularization at the world level (Halman and Draulans 2006; Pollack 2008; Pollack and Pickel 2009; Molteni and Biolcati 2018). We rely on a detailed portrait of the evolution and current status of religiosity indicators, especially in the Western world. However, while not denying the usefulness of these indicators, we will argue in this article that the evolution of statistical indicators of religiosity is limited in accounting for the actual transformations of the form and role of religion, and of Christian Churches, particularly in the European public sphere.

In recent years, the religious landscape has changed worldwide. Religion has globally gained visibility in both the public and especially political spheres, as illustrated by the rise of "Christian nationalism" before and during the Trump era (Whitehead and Perry 2020), the growth of populist "Christian" neo-nationalisms in Central and Eastern Europe (Casanova 2021) and the evangelical take on the political arena in many Latin American countries (Bárcenas Barajas 2021). The declining evolution of statistical indicators on religiosity did not predict this change, and neither did those parameters seem to have been affected by this transformation. Europe was initially considered immune to the upsurge of religion globally and was characterized as the "exceptional case" (Davie 2006). In fact, statistical 
indicators of religiosity still corroborate this diagnosis of Europe as the most secularized region in the world.

However, a closer examination of the role of religion in Europe portrays a far more complex picture. The empirical evidence depicts an ambivalent, volatile and even contradictory scenario for religion, which classical theorizations of religious change failed to capture. In her analysis of the role of the Catholic Church in France, Céline Béraud (2017) describes the situation as paradoxical: while quantitative indicators of religiosity are gradually declining, the Catholic Church has regained a strong public profile in recent years and has displayed a significant capacity to mobilize resources and people in supporting religious/moral causes. This situation is very similar in Spain. While religion is seeming to lose ground as a social force (Pérez-Agote 2007) and religious indicators have demonstrated a drastic fall over the last two decades $^{1}$, this has not had a direct translation or impact on the role of religion in the public sphere. The Catholic Church has followed a "deprivatization" strategy (Casanova 1994) and is increasingly claiming a voice in the public sphere (however, not always successfully). This has especially been the case since 2004, when the socialist government deployed its political agenda on matters of morality, particularly the legalization of same-sex marriage in 2005, which constituted a turning point event in the Spanish public sphere. On a different level, the recent irruption of an extreme-right party on the Spanish political scene has bolstered the use of religious markers in public debates and brought back Christianity as a symbolic resource in the public definition of national identity. Its growth is not different from that of other European countries such as France, Austria or the Netherlands, but it also holds some particularities which we discuss below.

Nonetheless, this new visibility of the Catholic Church in the public sphere does not directly translate into a major influence in the political agenda. In fact, an analysis of the so-called "morality policies" (Knill et al. 2014) shows that "Spain has one of the most permissive regulatory frameworks on morality issues in Europe" (Chaqués Bonafont and Roqué 2012). Abortion, stem-cell research, same-sex marriage and euthanasia are some of the morally charged issues that have been legally enforced in recent years against the views of the Catholic Church and despite its strong opposition campaigns. However, despite the Church's declining capacity to influence the political agenda on "morality issues", Catholicism still holds a privileged position in the welfare, education, health and heritage fields, enforced by the concordatarian agreements, signed by the Vatican state and the Spanish Government in 1979. Since then, the state has not reconsidered the economic prerogatives awarded to the Catholic Church, despite the secularization trends brought about by the democratic transition.

To summarize, the complex role of the Catholic Church in the public sphere cannot be accounted for in single terms. We therefore argue that lineal, homogenizing and dichotomic secularization approaches fail to capture the ambivalent form of Catholicism in contemporary Spain and of Christian churches in Europe more broadly. To overcome the limitations of classical secularization theories, we propose an alternative perspective in this article to understand the simultaneous coexistence of different "cultures of secularity" (Wohlrab-Sahr and Burchardt 2012) in the country, and the apparent paradoxical role of the Catholic Church in the public domain. More specifically, we advance an alternative approach that reconsiders two important elements: temporality and social space. Firstly, we propose adopting an "eventful temporality" (Sewell 2005) instead of a linear temporality. This enables the consideration of the impact of unexpected social and political events in altering the direction as well as shaping the public presence and form of religion. Secondly, we stress the need to focus our attention on understanding the specificity of the different fields in which religion is mobilized. The configuration and dynamics of each of those fields matter when explaining the role, shape and weight of Christian majority churches in contemporary European societies.

This article focuses on the case of Spain but it aligns with the research being done in other European contexts (Béraud 2017; Calkin and Kaminska 2020; Green-Pedersen and Little 2020). Methodologically, the article draws on empirical data, gathered within the 
framework of two research projects ${ }^{2}$, with the aim of making a theoretical contribution to rethinking the religion-politics-law nexus and the relationship between traditional indicators of religiosity and the public form and role of majority churches. These projects consist of qualitative studies based on interviews with religious, political and administrative actors concerned with religious matters as well as ethnographic research in particular institutional contexts and the analysis of media and parliamentary debates. We draw on the case of Spain and use the conceptual tools of "eventful temporality" and field-specific dynamics to examine the current form and impact of Catholicism in the public sphere. Specifically, we analyze the entanglements of Catholicism, politics and the law in the domains of welfare and public institutions, morality politics and the politics of belonging.

\section{Revisiting Secularization: Eventful Temporality and the New Conceptions of the Religion-Politics Nexus}

Classically, sociological accounts have predominantly analyzed religion, and more specifically, the public presence, political role and individual influence of historical churches, through the lens of secularization theories. Guided by the ideas of modernization, these explanations have delineated an abstract, linear, progressive and homogeneous process that predicted the decline of religion, as societies would become more economically and technologically developed and democratic. Several scholars, however, have challenged these predictions and assumptions. Three approaches are particularly significant. On the one hand, the concept of "multiple modernities" (Eisenstadt 2000) has been widely used to account for the different role that religion has adopted in various countries around the world. The argument behind this approach is that there is no single path, no unified conception of modernity, but divergent cultural, social, religious and political articulations. The concept of "multiple modernities", as its parallel of "multiple secularities" (Wohlrab-Sahr and Burchardt 2012), offers a new reading of modernity by complexifying the understanding of the articulation in relation to religion, modernity and secularity.

On the other hand, Peter Berger, in his book (1999) The Desecularization of the World, argued against the consideration of secularization as an irreversible process and illustrated his argument through the analysis of several case studies of the revitalization of religion in different world regions (Berger 1999). Berger offers a temporal critique to the secularization theory, arguing that linearity might be challenged and secularization reversed. His approach is thought-inspiring, since it challenges the idea of the inevitability of secularization and the unidirectional passage of time. However, at the same time, the main argument still holds a linear pattern (from secularization, to desecularization and back again).

Finally, in his book, Public Religions in the Modern World (1994), Casanova argued that secularization theory conflated the existence of three distinct sub theses-functional differentiation, the decline of individual religiosity and the privatization of religion-which should be analyzed as separate theses, since each of them responds to an autonomous logic. Casanova's approach is highly innovative since it disentangles secularization and identifies the different factors at work in each particular situation. In relation to our article, the most important sub-thesis, distinguished by Casanova, is that of the deprivatization of religion, which refers to the possibility of religion playing a role in the public sphere. From this perspective, we can understand that deprivatization might work against or in parallel to the indicators that measure individual religiosity. The disentanglement of secularization into three distinct theses permits to precisely uncover what might initially seem paradoxical, namely the renewed visibility of Catholicism in the public sphere, in a context in which indicators of affiliation to the Catholic Church and religious practice and belief are diminishing.

These three sociological contributions (multiple modernities/secularities; desecularization; and deprivatization) have already established the trend towards a more nuanced understanding of secularization in contemporary societies. However, in this article, we argue that in order to explain the current role and form of Christian churches in contemporary Europe, it is necessary to go one step further. For this reason, we propose an approach that reconsiders the temporal and contextual dimensions. Firstly, we suggest replacing tele- 
ological and transhistorical notions of temporality with an "eventful" notion (Sewell 2005), which considers contingency and agency. Sewell's mode of conceptualizing temporality in historical sociology as advancing and being shaped by specific events, helps us revisit the secularization thesis. More specifically, he defines social life "as being composed of countless happenings or encounters in which persons and groups of persons engage in social action" (Sewell 2005, p. 100), in an eventful temporality that recognizes the importance of "unexpected, and inherently unpredictable events" in history (Sewell 2005, p. 102). From this perspective, while not completely denying the existence of long-term processes, we advocate understanding religious processes as being open-ended and discontinuous, rather than deterministic and predictable. We, therefore consider contingencies and changing directions in our analysis (Boltanski 2018; Wagner 2015). Adopting of this approach implies the rejection of the idea that secularization is an irrevocable process and the abandonment of the notion that it is possible to identify a clear pattern of desecularization. The role of religion in society is shaped by specific events that might change the course of history, which may be cyclical.

Secondly, we advocate the need to take into account the specific contextual dynamics that shape distinct fields, such as national security, education, welfare, economy, morality politics and national identities, when researching the role of religion in contemporary societies. This is more fruitful, we argue, than the search for abstract, all-encompassing and homogenizing secularization patterns at the national level. In the following paragraphs, we consider that secularization does not impact in the same way on each of the different fields which exist in contemporary societies. The specific dynamics and particular characteristics of each field affect the role given to religion within it. Three elements of such dynamics stand out: the actor constellations, the issues at stake and the discursive repertoires, specific to each field of social life. Likewise, it is important to understand that the religious-secular binary is articulated, disputed and constrained differently across the different fields of social life. In this article, we identified three main fields in which the Catholic Church is currently operating in Spain, and also in which religion, politics and the law are inextricably linked to one another. The first is the field of public services, which reflects the historical relationship between state institutions and the Catholic Church in areas such as social services, security and cultural policies. The second field is the domain of morality politics, characterized by the regulation of highly sensitive issues at the intersection of the body, science and the family. The third alludes to the politics of belonging, that is, the entanglement of religious and national identities in public and political discourse.

At a theoretical level, it is also important to add that while religion has been traditionally considered the "independent variable" that explained the political behavior of individuals and influenced the political sphere, we adopt a different approach here. Recent scholarly developments have already challenged this assumption of religion as always being the independent variable. Research carried out by Margolis (2018) on the US showed that politics also has the capacity to alter religion, by indicating that partisanship dynamics can change individual religious behavior. Politics might then become the independent variable. Margolis' original approach offers a new reading of the religion-politics nexus. Nonetheless, in this article, we argue that religion might work as the dependent or the independent variable, depending upon the field in which it is operating, and on the specific circumstances involved. Therefore, to understand the changing shape of the entanglement between Christian churches and politics, it is necessary to go beyond the dichotomic analyses of these two spheres, as if these were homogeneous, stable and firmly bound realities.

\subsection{Banal Catholicism: Public Services and the State-Church Regime}

In April 2017, an internal order from the Spanish Ministry of Defense stated that "the national flag shall be flown half-mast in all units, bases, centers and barracks from $2 \mathrm{pm}$ on Holy Thursday until 00:01 (midnight) of Resurrection Sunday" to commemorate the death of Jesus Christ. This included the Defense Ministry headquarters. This measure, 
regulating the use of the half-mast, which is at the edge of the $684 / 2010$ royal decree, was already justified by the Ministry of Defense, both in 2013 and 2014, alluding to the respect for freedom of religion. In response to a parliamentary enquiry by the Socialist Party in 2014, the conservative government affirmed that "[ $t]$ he half-mast flying of the national flag at certain dates is part of the secular tradition of the armies and is integrated into the normality of the events of the internal regime that are celebrated in the military units" (El País, 15 April 2017, referring to Granada Hoy, 29 July 2014). Drawing on a judgement from the Constitutional Court, the government added that "[w]hen a religious tradition is integrated into the social fabric of a particular group, it cannot be assumed that through it, public authorities intend to transmit support or adherence to religious postulates". This vignette illustrates the prevalence of traces of the historical Catholic Church establishment in Spain. However, this is not an exception as there still is a multiplicity of practices, symbols and customs that contribute to the strengthening of the role of the Catholic Church in the public sphere.

Religious signs and traces go usually unnoticed and are even invisible under the veil of the ordinary, the routine and what is defined as "normal". In our research, we observed many practices that have benefited from the invisibility of Catholic hegemony, ranging from the "unnoticed" presence of statues of the Madonna in prison facilities (Griera and Clot-Garrell 2015; Martínez-Ariño et al. 2015), the reprieve of an inmate at Easter, the obligation of building a Catholic chapel in every public hospital (Martínez-Ariño and Griera 2018) or the celebration of an "official mass" in local township celebrations. The term "banal Catholicism" that we coined elsewhere (Griera and Clot-Garrell 2015; Griera et al. 2015) helps to capture the many non-problematized Catholic references that prevail in Spanish state institutions and explain the persistence of traces of historical religious monopolies in public contexts.

The idea of banality - and the unforeseen social, political and cultural relevance of the acts, narratives and objects, socially considered banal-has fostered important philosophical and sociological conceptualizations, including Arendt's notion of the "banality of evil" (1964) and later, Billig's concept of "banal nationalism" (1995). Scholars have understood and used banality differently, but they all agree with the idea that power is exercised and manifested, not only in noticeable, visible and explicit ways, but first and foremost through invisible and ordinary practices, discourses and objects ${ }^{3}$. Drawing on Billig's concept, we argue that "banal nationalism" went hand in hand with "banal Christianity" in most European countries. Through routine practices, discourses and objects embedded in everyday life, such as the organization of the calendar, the architectural landscape of most cities and the existence of chapels in hospitals and prisons, European nations were not only produced and reproduced as nations, but also as "Christian nations". The hegemony of Christianity was based not only on the tight coupling between the ideas of the nation and of the Christian nation but also through the churches' historical embeddedness in many areas of social life, from law to heritage, education and the provision of welfare. This embeddedness is currently visible in the wide array of practices, discourses and objects of Christian origin in public institutions and spaces, such as those illustrated above. Such Christian traces are perceived as normal and compatible with state secularism, showing that religious elements coexist with secularization dynamics.

Although this public hegemony of Christian churches proves enduring, as the notion of banality underlines, this should not be understood as a permanent and stable state of affairs. Taking into account a historical perspective with an eventful understanding of temporality, it is important to consider social, cultural and political processes and happenings that could potentially make problematic practices, discourses and symbols which until now have been banal. Nonetheless, historical inertia marks the trends in the state-church domain, as all these symbols and practices are deeply ingrained in the functioning of public institutions.

Additionally, the banal character of the Catholic traces is sustained by the privileged position of the Catholic Church in the legal, economic and cultural matrix of the state. The 
Spanish state-church regime, which was established at the beginning of the contemporary democratic period, has remained almost intact during the last four decades. The legal system has not been updated to reflect social and religious changes. For this reason, the signature of the agreements between the Spanish government and the Vatican State in 1979 can be considered a turning point event that stabilized the current embeddedness of the church in the institutional matrix of the state. It also prevented that the secularization of Spanish society would translate into the complete institutional removal of the Church's influence. This predominance of Christianity is also visible in other areas, such as the provision of welfare services. In the Spanish case, this was particularly salient during the 2008 financial crisis but also in the current economic and social crisis caused by the COVID-19 pandemic. As Itçaina (2019) demonstrates, despite a strong and increasingly secularized society in terms of the three Bs explained above, Catholic institutions have been successful in maintaining a rather strong welfare network, and in creating a wide network of collaboration between Catholic institutions and public services.

\subsection{Morality Politics: The Re-Articulation of the Religious-Secular Cleavage}

After years of public debate, the Spanish Parliament passed a law legalizing euthanasia on 17 December 2020. Supported by a large majority of the members of parliament, this law was backed by more than $80 \%$ of Spaniards ${ }^{4}$. However, this support did not prevent the conservative People's Party (PP) and the far right-wing party, Vox, from strongly opposing the law, despite their own voters' support for it. Certain members of these parties accused the government of "acting like Nazis" (Agustín Rosety, Vox MP), favoring a "culture of death" (Santiago Abascal, Vox MP) 5 and promoting euthanasia to lower healthcare spending (Jose Ignacio Echániz, PP) ${ }^{6}$.

The evolution of the controversies relating to moral issues in Spain, such as the aforementioned, shows an interesting and yet contrasting reality with respect to the state-church politics, previously described. Public debates on moral issues such as abortion, same-sex marriage, euthanasia or LGBTQI+ rights laws were almost absent from the political agenda during the first 25 years of the current democratic period. However, these have gained salience from 2004 onwards. Despite morality politics moving with the secularization of society, as described by the three Bs -more people declared themselves members of the Catholic Church in the 1980s and 1990s than in the 2000s (Pérez-Agote 2007), two specific reasons account for this absence. On the one hand, in the first few years of democracy after the Spanish dictatorship, there was a tacit agreement among Spanish political parties not to reactivate the religious-secular divide (Chaqués Bonafont and Roqué 2012). On the basis of the lesson learned from the Second Spanish Republic (1931-1936), politicians felt that the religious-secular divide could potentially divide society and threaten the recently established democracy. As Linz stated, in the "crucial constituent period both sides... [have] shown a remarkable desire for religious peace" (1980, p. 277), which translated into the elites' commitment to keep potentially controversial issues, such as those belonging to the terrain of the "moral politics", low key.

On the other hand, Linz also observed that "should one or the other side opt for mobilizing their constituencies on these issues, Spanish society is potentially divided by religious attitudes along a left-right continuum" (1980, p. 270). Thus, despite the commitment of political and religious elites to not raise the religious flag in the political sphere, the religious-secular divide remains latent and can be reactivated at any time, thereby disrupting this tacit consensus. This occurred in 2004, when former socialist Prime Minister, José Luis Rodriguez Zapatero and his government adopted more permissive regulations on abortion, same-sex marriage and medical procedures, such as assisted reproductive technologies and stem cell research. These events fueled the religious-secular divide and created a fertile ground for the mobilization of religious actors. In 2004, the Catholic hierarchy and Catholic organizations and movements marched at the front of a conservative demonstration for the first time since the end of the dictatorship in the late 1970s. 
These regulations show how a particular occurrence can alter the course of history and bring religion back into the public sphere. Since, public controversies around "moral issues" have gained public attention and become battlegrounds for competing political projects. The Church switched its strategy of invisibility, dominant the last decades of the 20th century, to one of active propagation of Christian moral positions. There has been a process of "scandalization" of moral issues, encouraged by new strategies in the Church's mobilization. In recent years, religious activists have transcended religious circles and shifted their mobilization to the courts, parliament, the streets and TV shows (Cornejo-Valle and Pichardo 2018, 2020). There is a process of "NGOisation of religious activism" (Vaggione 2005) that works in consonance with the increasing relevance of certain conservative Catholic movements (e.g., Neocatechumenal and Comunión y Liberación). This shift, unpredictable from a linear understanding of time, is not exclusive to the Spanish case. The battle on moral issues is present all over Europe. Christian churches have fostered new political mobilization strategies around moral issues, especially in countries with a strong religious-secular cleavage. In France, for example, while the Catholic Church is no longer a majority church according to traditional religious indicators, it still retains social power, which it can easily activate to provoke "moral panic" (Béraud 2014).

The agenda-setting in "morality politics" and questioning of tacit moral agreements is usually carried out by left-wing parties. It is thus important to take into account the actor constellations and issues at stake, to understand the dynamics in this domain. As noted by Green-Pedersen (2007), it is usually political parties on the left that try to gain political advantage when highlighting issues that they "own". The promotion of a progressive moral agenda has been perceived as part of the leftist emancipatory and modernization project. These are topics that do not generate much divide in their electorate but stand as "symbolic markers" that clearly identify them as "secular" and different from right-wing parties. In turn, right-wing political parties tend not to bring moral issues into the political agenda when they are in government. As Engeli et al. stress, "although it may sound counter-intuitive, Christian Democratic parties may (...) often try to avoid rather than appreciate morality issues, because morality debates can easily mobilize the confessional voters and grass-root activists and thereby threaten the broad appeal of the party" (2013, p. 339). In Spain, the conservative People's Party has mainly pushed "moral issues out of the political agenda ( . . . ) to consolidate a situation of non-decision" (Chaqués Bonafont and Roqué 2012, p. 63).

\subsection{The Politics of Belonging: Religious Markers and National Identity}

In September 2019, the Spanish Supreme Court granted permission for the exhumation of the former dictator, Francisco Franco. A month later, the remains of Franco were removed from a national religious monument, the epitome of his own version of nationalCatholicism and taken to a private family mausoleum in Madrid. Socialist Prime Minister, Pedro Sánchez, declared this a necessary step to achieve full democratization and included the exhumation of the dictator's corpse as part of the wider politics of memory. Several members of the Catholic hierarchy voiced their opposition to this decision, as well as many right and far right-wing deputies. Finally, the Vatican, through its state secretary, Pietro Parolin, forced the Spanish Catholic hierarchy to accept the decision ${ }^{7}$.

The opposition of certain members of the Spanish Catholic hierarchy to the exhumation indicates the reticence to accept some of the most fundamental changes undergone in Spanish society. National Catholicism —an ideology that linked Spanish national identity with Catholicism, which the Franco regime strengthened and relied upon-had begun to lose legitimacy in contemporary Spanish society since the 1970s (Burrieza Sánchez 2019). Despite the mainstream discourse that characterizes Spanish society as secularized and religiously plural since the democratic transition, the exhumation of Franco's remains made visible the contested link between national identity and Catholicism. The entrance of the far right-wing party, Vox, in the Spanish Parliament in 2019, following the populist right-wing trend all around Europe, has heightened this mobilization of the Catholic identity ${ }^{8}$. Since 
its foundation, Vox has anchored its identity discourse in a nostalgic vision of the "Christian past" and in an active and aggressive discourse against Islam. The transformation of the Spanish religious landscape in recent years, with the growth of global migration flows, generated fertile ground for the emergence of "nativist" discourses, most of them directed against Muslims.

These nativist discourses reinterpret Spanish history, bringing into discussion the historical presence and role of Islam in the Peninsula. Vox President, Santiago Abascal, strategically uses the term "Reconquista" (Reconquest)—which refers to the expulsion of Muslims from the Peninsula by the Catholic Kings between the 8th and the 15th centuriesto talk about the present and to frame the party's nativist political project ${ }^{9}$. Vox promotes a reading of history in which Islam is identified as alien to the country and a threat to the nation. This discursive repertoire is strategically activated at specific moments (e.g., when a Muslim deputy is elected), and crystalizes, in particular, in relation to certain controversies, such as that of the ownership of the Córdoba mosque-cathedral (Astor et al. 2019) or the inclusion of Islamic religious education in public schools (Bourekba 2018). Similar to the case of France (Ferrara 2019), Spanish identity is increasingly articulated by this extreme right-wing party in favor of Christianity and in opposition to Islam. The "clash of civilizations" (Huntington 2000) operates as the cultural matrix in which the Spanish identity is instrumentally anchored in times of crisis and social distress. This discourse relates to what Brubaker has called "civilizationism", a form of populism spreading in many European countries where "Christianity is embraced not as a religion but as a civilizational identity understood in antithetical opposition to Islam" (Brubaker 2017, p. 1194). However, the nationalist element remains quite prominent in the Spanish case, primarily as a response to the growth of the Catalan nationalist movement and its strong mobilization in the last 10 years.

Hervier-Léger coined the term "Catholicisme ostensible" (conspicuous Catholicism) to refer to the efforts of certain Catholic actors and right-wing groups, to make Catholicism visible in the public sphere. This conspicuity seems to be related to the passage from a majority to a minority status (Béraud 2017). However, the use of Catholicism by these groups is not always necessarily linked to committed beliefs. As several scholars have argued (Astor and Mayrl 2020; Astor et al. 2017; Beaman 2013, 2020), there is a process of the culturalization of religion, whereby the majority Christian symbols are stripped of their religious meaning and presented as part of the national culture. An example of this is the mobilization of Vox to protect Christian crosses as an asset of cultural interest, because of their link to Spanish history. This is not different from examples in other countries, in which Christian symbols are protected because they are considered as part of the cultural and national heritage (Beaman 2013).

Nonetheless, this exhortation of a Catholic national identity that has recently taken place as a result of an extreme right-wing party's strategy, seems to permeate other political sensibilities. In a party event, celebrated in a crowded theatre in the city of Murcia in 2018, the General Secretary of the People's Party, Teodoro García Egea, cheered on the mayor, a party member, for his action concerning the celebration of Christmas and claimed:

Mr. mayor, you have put Murcia beyond many European capitals with regard to the celebration of Christmas. Because we celebrate Christmas, we display the Nativity scene, we display the Christmas tree, we celebrate our traditions, Easter, and we feel very proud of it! And whoever doesn't like it, can turn around. Because we are SPANIARDS! And we celebrate Christmas and Easter, and we are very proud of our farmers and we defend hunting, and we defend those who want to go and watch bullfighting, so they can go, and those who don't want to go, then they shouldn't go but nothing should be prohibited! ${ }^{10}$.

In his impassioned discourse, applauded by the public, he implicitly questions those in the political spectrum, who are more reticent regarding the display of religious symbols in public and the identification of state authorities with religion. Moreover, he equates celebrating Christmas and Easter, as well as hunting and watching bullfighting with being 
a proud Spaniard. All these issues work as symbolic markers that spark controversy and put religion at center stage for strategic purposes. As Euchner maintains, "[r]eligion did not disappear in modern times; instead, a small number of religious agents (e.g., churches and politicians) are sufficient to stimulate competition with actors defending secular ideologies (Davie 2006) and hence to increase attention on value-loaded issues" (Euchner 2019, p. 35). This strategic use of Catholicism is particularly dependent upon the political agenda and party politics. In the Spanish case, a defense of Catholicism at all costs at certain times may well be a temporary strategy of the parties of the political right to differentiate themselves from one another and to present themselves as best representing Spanish identity.

\section{Discussion and Conclusion}

The current entanglements of Catholicism, politics and the law in contemporary Spain are full of tensions and frictions, which challenge linear and single-cause interpretations of the evolution and role of religion in contemporary Western societies. Our analysis has shown the relevance of an approach to temporality that takes into account contingency and agency in terms of large-scale and long-term phenomena. Likewise, we have demonstrated the importance of considering context-specific dynamics (i.e., actor constellations, issues at stake and discourse repertoires) that shape different areas of public life in terms of understanding secularization as a heterogeneous, rather than a uniform process. It is thus necessary to examine the irruptions and interruptions, the unexpected and unpredictable events, as well as the action of particular actors that shape religious processes and the contours of historical churches.

The influence of the Catholic Church in the political and legal realms generates an ambivalent image. While Spain can be understood as a "fully secularized" country from the perspective of morality politics, the evolution and role of the Catholic Church in the provision of public service points in a different direction. In parallel, far-right, nationalpopulist and conservative political parties increasingly use Christianity strategically, as a symbolic marker of national identity in the politics of belonging. The variety in the form and influence of Christianity in the different domains can be better captured when the relationship between religion, politics and law is not constricted to one fully encompassing narrative that disregards social action.

The analysis of specific contexts enables the observation of the complex entanglements of different actors. On the one hand, left-wing parties have adopted a very active role in promoting progressive morality politics and have used secularism as a political emblem to push for a more liberal understanding of moral- and bio-politics. On the other hand, rightwing and conservative parties have tried to distance themselves from these controversies with a twofold aim: first, being "catch-all parties" and second, mobilizing a definition of the national subject at the intersection of two dichotomous political categories, the secular/religious divide and the contraposition of Islam and Christianity. Conservative Christian movements have also actively participated in moral public debates and fueled Christianity's public visibility through the use of repertoires of collective action. At a conceptual level, an examination of the different domains has shown that the separation between the secular and the religious domains does not draw a universal, formal, aprioristic boundary, but this is a contingent and context-sensitive distinction. As Wohlrab-Sahr and Burchardt state "the entanglements of religion and politics must be viewed as sites in which the boundaries between religion and secular spheres are negotiated, challenged and redrawn" (2012, p. 882).

The interplay between Christianity, politics and the law, analyzed in each of the three public domains, rather than articulating stable patterns, produces assemblages which are subjected to the impact of disruptive events. Moreover, the distinct domains are not only subjected to this discontinuous temporality but operate in different temporalities. While the banality of Catholicism draws on the long-term temporality that sustains it, the strategic activation of Christianity in discussions relating to morality politics and the politics of belonging, occurs more abruptly, when events such as the passing of the euthanasia law 
or the exhumation of the dictator's remains uncover the secular-religious divide. Finally, the actor constellations, issues at stake and discursive repertoires, mobilized in the various domains, reflect the political and religious histories specific to each country. Future crosscountry comparative research considering these contextual aspects would shed light on the different forms that these assemblages take.

Author Contributions: All authors contributed equally. All authors have read and agreed to the published version of the manuscript.

Funding: This research received no external funding.

Institutional Review Board Statement: Not applicable.

Informed Consent Statement: Not applicable.

Data Availability Statement: Not applicable.

Conflicts of Interest: The authors declare no conflict of interest.

\section{Notes}

1 According to the Spanish Barometer, while 82\% of the Spanish population self-identified as Catholic in 2001, only $49.5 \%$ did so in 2021 (Centro de Investigaciones Sociológicas 2021). To date, $69 \%$ of the population never or hardly ever attend mass outside of big celebrations (Centro de Investigaciones Sociológicas 2021) and only 3\% consider religion as one of the most important values (Eurobarometer 2012). Moreover, despite the fact that two thirds of the population identify as Catholic, secular rituals have displaced religious rituals. In 1980, 96\% of marriages were Catholic ceremonies, a figure that dropped to $60 \%$ in 2005 and to less than $22 \%$ in 2019 . While these transformations are not exclusive to Spain, and other countries like Italy and Portugal have experienced similar developments, the change has been more greatly accentuated in Spain.

2 The two research projects have been carried out in the framework of the research group ISOR on sociology of religion, at the Universitat Autònoma de Barcelona. The first was entitled "The management of religious diversity in prisons and hospitals in Spain” (2010-14), and the second “Urban Religious expressions in the public space in Madrid and Barcelona" (2016-20) both funded by the Spanish National Research Program.

3 In the study of the mediatization of religion, Hjarvard (2011) proposed the term "banal religion" to refer to the unnoticeable religious elements and practices represented by the media which differ from the structured and explicit forms of institutionalized religion. Similarly, Oliphant (2021) writes about the banality of Catholicism in France and its pervasiveness in spaces outside churches, such as museums, architecture or the political arena.

4 See https://www.lavanguardia.com/vida/20180715/45870735547/mayoria-espanoles-apoya-eutanasia-enfermo s-no-terminales-ramon-sampedro.html (accessed on 2 February 2021). See also Serrano del Rosal and Cerro (2018).

5 See https://www.elespanol.com/espana/politica/20201217/Vox-compara-ley-eutanasia-actuaciones-hitler-anos /544196677_0.html (last accessed on 2 February 2021).

6 See https:/ / www.elperiodico.com/es/politica/20200211/pp-eutanasia-politica-de-recortes-echaniz-7844206 (last accessed on 2 February 2021).

7 See https:/ / english.elpais.com/elpais/2019/02/21/inenglish/1550737536_140091.html (accessed on 2 February 2021).

8 It is important to highlight that data that combine religious and political self-identification show a higher proportion of self-identified Catholics among those who locate themselves in the right rather than in the extreme right of the political spectrum (Centro de Investigaciones Sociológicas 2021).

9 See https://www.opendemocracy.net/en/can-europe-make-it/Vox-and-spanish-muslim-community-new-recon quista-of-spa/ (last accessed on 2 February 2021).

10 See https://www.youtube.com/watch?v=8C-oNMAJmSE (last accessed on 2 February 2021).

\section{References}

Astor, Avi, and Damon Mayrl. 2020. Culturalized religion: A synthetic review and agenda for research. Journal for the Scientific Study of Religion 59: 209-26. [CrossRef]

Astor, Avi, Marian Burchardt, and Mar Griera M. 2017. The politics of religious heritage: Framing claims to religion as culture in Spain. Journal for the Scientific Study of Religion 56: 126-42. [CrossRef]

Astor, Avi, Marian Burchardt, and Mar Griera M. 2019. Polarization and the limits of politicization: Cordoba's Mosque-Cathedral and the politics of cultural heritage. Qualitative Sociology 42: 337-60. [CrossRef] 
Bárcenas Barajas, Karina. 2021. Antagonismos en el espacio público entorno a la "ideología de género": expresiones del neoconservadurismo católico y evangélico en México. In Religiones y Espacios Públicos en América Latina. Edited by René de la Torre and Pablo Semán. México: Clacso.

Beaman, Lori. 2013. Battles over Symbols: The Religion of the Minority versus the Culture of the Majority. Journal of Law and Religion 28: 67-104. [CrossRef]

Beaman, Lori. 2020. The Transition of Religion to Culture in Law and Public Discourse. Abingdon: Routledge.

Béraud, Céline. 2014. Un front commun des religions contre le mariage pour tous? Contemporary French Civilization 39: 335-50. [CrossRef]

Béraud, Céline. 2017. Ce que l'épisode du mariage pour tous nous dit du catholicisme français. Revue du MAUSS 1: 327-37. [CrossRef]

Berger, Peter. 1999. The Desecularization of the World. Washington, DC: Ethics and Public Policy Center.

Boltanski, Luc. 2018. Historical sociology and sociology of history. Social Imaginaries 4: 45-70. [CrossRef]

Bourekba, Moussa. 2018. Discursos estereotipados sobre los musulmanes en España: De moro a musulmán, de islam a musulmanes. In Una Realidad Incontestable: Islamofobia en los Medios. Barcelona: IEMed i Fundación Al Fanar.

Brubaker, Rogers. 2017. Between nationalism and civilizationism: The European populist moment in comparative perspective. Ethnic and Racial Studies 40: 1191-226. [CrossRef]

Burrieza Sánchez, José. 2019. El Nacionalcatolicismo: Discurso y Práctica. Madrid: Cátedra.

Calkin, Sydney, and Monika Ewa Kaminska. 2020. Persistence and change in morality policy: The role of the Catholic Church in the politics of abortion in Ireland and Poland. Feminist Review 124: 86-102. [CrossRef]

Casanova, José. 1994. Public Religions in the Modern World. Chicago: University of Chicago Press.

Casanova, José. 2021. Transnationalism and Religion: The European Union, from Christian-Democratic Project to Secular Cosmopolitanism, to Populist 'Christian' Neo-Nationalisms. In Religion and Neo-Nationalism in Europe. Edited by Florian Höhne and Torsten Meireis. Baden: Nomos Verlag.

Chaqués Bonafont, Laura, and Anna M. Palau Roqué. 2012. From prohibition to permissiveness: A two-wave change on morality issues in Spain. In Morality Politics in Western Europe. Edited by Isabelle Engeli, Christoffer Green-Pedersen and Lars Thorup Larsen. London: Palgrave Macmillan, pp. 62-87.

Centro de Investigaciones Sociológicas. 2021. Barómetro de Febrero de 2021. Available online: http://www.cis.es/cis/opencm/ES/11_ba rometros/index.jsp (accessed on 13 April 2021).

Cornejo-Valle, Monica, and José Pichardo. 2018. Actores y estrategias en la movilización anti-género en España: el desplazamiento de una política de iglesia al activismo laico. Revista Psicología Política 18: 524-42.

Cornejo-Valle, Monica, and José Pichardo. 2020. The Ultraconservative Agenda Against Sexual Rights in Spain: A Catholic Repertoire of Contention to Reframe Public Concerns. In Public Discourses About Homosexuality and Religion in Europe and Beyond. Edited by Marco Derks and Mariecke van den Berg. Cham: Palgrave Macmillan.

Davie, Grace. 2006. Religion in Europe in the 21st century: The factors to take into account. European Journal of Sociology/Archives Européennes de Sociologie 47: 271-96. [CrossRef]

Eisenstadt, Shmuel. 2000. Multiple Modernities. Daedalus 129: 1-29.

Euchner, Eva-Maria. 2019. Morality Politics in a Secular Age. Cham: Palgrave Macmillan.

Eurobarometer. 2012. “The Values of Europeans". Standard Eurobarometer 77. Available online: https://ec.europa.eu/commfrontoffice/ publicopinion/archives/eb/eb77/eb77_value_en.pdf (accessed on 2 February 2021).

Ferrara, Carol. 2019. "The catholicness of secular France", EuropeNow Daily, Council for European Studies. Available online: https:/ / www.europenowjournal.org/2019/10/02/the-catholic-ness-of-secular-france/ (accessed on 2 February 2021).

Green-Pedersen, Christoffer. 2007. The conflict of conflicts in comparative perspective: Euthanasia as a political issue in Denmark, Belgium, and the Netherlands. Comparative Politics 39: 273-91.

Green-Pedersen, Christoffer, and Conor Little. 2020. Without enemies, without friends. Morality policies, the Roman Catholic Church, and Ireland's 'secular' party system. Journal of European Public Policy. [CrossRef]

Griera, Mar, and Anna Clot-Garrell. 2015. Banal is not trivial: Visibility, recognition, and inequalities between religious groups in prison. Journal of Contemporary Religion 30: 23-37. [CrossRef]

Griera, Mar, Julia Martínez-Ariño, Anna Clot-Garrell, and Gloria García-Romeral. 2015. Religión e instituciones públicas en España. Hospitales y prisiones en perspectiva comparada. Revista Internacional de Sociología 73: 1-13. [CrossRef]

Halman, Loek, and Veerle Draulans. 2006. How secular is Europe? The British Journal of Sociology 57: 263-88. [CrossRef] [PubMed]

Hjarvard, Stig. 2011. The mediatisation of religion: Theorising religion, media and social change. Culture and Religion 12: 119-35. [CrossRef]

Huntington, Samuel. 2000. The clash of civilizations? In Culture and Politics. New York: Palgrave Macmillan, pp. 99-118.

Itçaina, Xavier. 2019. The Spanish Catholic Church, the public sphere, and the economic recession: rival legitimacies? Journal of Contemporary Religion 34: 153-72. [CrossRef]

Knill, Christoph, Caroline Preidel, and Kerstin Nebel. 2014. Brake rather than barrier: The impact of the Catholic Church on morality policies in Western Europe. West European Politics 37: 845-66. [CrossRef]

Lewis, Andrew R. 2021. Featured Book Review Essay: Christian Nationalism and the Remaking of Religion and Politics, by Andrew L. Whitehead and Samuel L. Perry. Sociology of Religion 82: 111-15. [CrossRef]

Linz, Juan. 1980. Religion and politics in Spain: From conflict to consensus above cleavage. Social Compass 27: 255-77. [CrossRef] 
Margolis, Michele F. 2018. From Politics to the Pews: How Partisanship and the Political Environment Shape Religious Identity. Chicago: University of Chicago Press.

Martínez-Ariño, Julia, and Mar Griera. 2018. Catholic chaplains in public institutions: Contextual opportunities and institutional inertia in Spanish hospitals and prisons. Journal of Religion in Europe 11: 138-60. [CrossRef]

Martínez-Ariño, Julia, Gloria García-Romseral, Gemma Ubasart-González, and Mar Griera. 2015. Demonopolisation and dislocation: (Re-) negotiating the place and role of religion in Spanish prisons. Social Compass 62: 3-21. [CrossRef]

Molteni, Francesco, and Ferruccio Biolcati. 2018. Shifts in religiosity across cohorts in Europe: A multilevel and multidimensional analysis based on the European Values Study. Social Compass 65: 413-32. [CrossRef]

Oliphant, Elayne. 2021. The Privilege of Being Banal. Chicago: University of Chicago Press.

Pérez-Agote, Alfonso. 2007. El proceso de secularización en la sociedad española. Revista CIDOB d'Afers Internacionals 77: 65-82.

Pollack, Detef. 2008. Religious change in Europe: Theoretical considerations and empirical findings. Social Compass 55: 168-86. [CrossRef]

Pollack, Detlef, and Gert Pickel. 2009. Church-State relations and the vitality of religion in European comparison. In Church and Religion in Contemporary. Wiesbaden: VS Verlag für Sozialwissenschaften, pp. 145-66.

Serrano del Rosal, Rafael, and Adrian Heredia Cerro. 2018. Actitudes de los españoles ante la eutanasia y el suicidio médico asistido. Revista Española de Investigaciones Sociológicas 161: 103-20.

Sewell, William H., Jr. 2005. Logics of History: Social Theory and Social Transformation. Chicago: Chicago University Press.

Vaggione, Juan Marco. 2005. Reactive politicization and religious dissidence: The political mutations of the religious. Social Theory and Practice 31: 233-55. [CrossRef]

Wagner, Peter. 2015. Interpreting the Present-A Research Programme. Social Imaginaries 1: 105-29. [CrossRef]

Whitehead, Andrew L., and Samuel L. Perry. 2020. Taking America Back for God: Christian Nationalism in the United States. Oxford: Oxford University Press.

Wohlrab-Sahr, Monika, and Marian Burchardt. 2012. Multiple secularities: Toward a cultural sociology of secular modernities. Comparative Sociology 11: 875-909. [CrossRef] 